\title{
Production and Economic Analysis of Oyster Mushroom (Pleurotus florida)
}

\author{
K. Chitra ${ }^{*}$, R. Venkatesh, K. Dhanalakshmi, P.T. Sharavanan, C. Bali Sasikumar \\ and K. Karthikeyani Vijayakumari
}
Anbil Dharmalingam Agricultural College and Research Institute, Tiruchirappalli-27, Tamil Nadu, India

*Corresponding author

\section{A B S T R A C T}

\section{Keywords \\ Pleurotus mushroom, Oyster, Paddy straw, Economics, TNAU \\ Article Info \\ Accepted: \\ 04 August 2018 \\ Available Online: \\ 10 September 2018}

Present investigation was carried out in the Mushroom Production Unit, Department of Plant Protection, Anbil Dharmalingam Agricultural College \& Research Institute, Tiruchirappalli from January 2018 to April 2018. Mushroom cultivation can directly improve livelihoods through economic, nutritional and medicinal contributions. But, mushrooms cultivation in a commercial way is underway. However, visualizing mushroom cultivation as a sustainable tool is a new challenge. Keeping this in mind, the students were trained and motivated to grow oyster mushroom. This training has given confidence to the students to take up this as a business in future. During the study, the production and economy analysis of oyster mushroom were observed.

\section{Introduction}

Mushrooms, a group of fungi (macro fungus), which lacks chlorophyll and grows either parasitically or saprophytically. Mushrooms with their flavor, texture, nutritional value and high productivity per unit area have been identified as an excellent food source to alleviate malnutrition in developing countries (Eswaran and Ramabadran, 2000). Mushrooms contain $20-35 \%$ of protein (dry weight), are low in lipids and contain all the nine essential amino acids (Kalac, 2009). Mushroom has been widely cultivated since the 1700's and presently more than 30 unknown species are cultivated as foods. Oyster mushroom (Pleurotus spp.), commonly known as "Dhingri" in India, is a lignocellulose loving fungus growing in nature on living or dead tree trunks/stumps or bark. They are easily recognized in nature due to their peculiar morphology with an eccentric short stem or stipe. The Oyster mushroom has been found to be ideal for people suffering from anaemia, hyperacidity, and constipation. Oyster mushrooms are native to Northeastern United States. Pleurotus species (oyster fungus) is an edible mushroom having excellent flavour and taste (Shah et al., 2004).

Oyster fungus is rich source of proteins, minerals and vitamins (Caglarirmak, 2007). Cultivation of oyster mushroom has increased tremendously throughout the world because of their abilities to grow at a wide range of temperature and utilizing various agro-based residues. Growing oyster mushrooms convert a high percentage of the lignocellulosic 
substrate to fruiting bodies increasing profitability. It requires a short growth time in comparison to other edible mushrooms.

Mushroom survival and multiplication are related to a number of factors, which may act individually or have interactive effects among them (AMGA, 2004). Temperature is one of the most important physical factors affecting the growth and development of oyster mushroom. The oyster mushroom confers advantages over other mushrooms for its ability to grow on wide range of temperature from 18 to $30^{\circ} \mathrm{C}$ and fast mycelial growth coupled with rapid colonization of substrates are the other characteristics features of this species (Rajarathnam and Bano, 1987). Hence, there is vast potential for the cultivation of oyster mushroom. The temperature determines the mycelial growth as well as fruit bodies production. Keeping these objectives inview present investigation was taken up.

\section{Materials and Methods}

Present investigation was carried out in the Mushroom Production Unit, Department of Plant Protection, Anbil Dharmalingam Agricultural College and Research Institute, Tiruchirappalli from January 2018 to April 2018. The details of various material and methods employed during the investigation are as under:

\section{Preparation of substrate}

Paddy straw is chopped into bits of size $5 \mathrm{~cm}$ for easy handling and operation and these substrates was soaked in water for about 8 hours to get wet and achieved $65-70 \%$ of moisture content All these wet substrates were separated from water and excess water was removed properly and then boiled the contents for 1 hour. After cooling, the substrates were thus ready to be used in mushroom cultivation (Srivastava and Bano, 2010).
All instruments, glassware's and culture media were sterilized by autoclaving with $15 \mathrm{psi}$ at $121^{\circ} \mathrm{C}$ for $1-2$ hours. The culture room of the laboratory was cleaned by gently washing with $70 \%$ ethyl alcohol.

The students were prepared mushroom bags for mushroom cultivation at the periodic interval for continuous harvesting of mushroom.

\section{Cost related to mushroom production}

\section{Cost of cultivation}

Cost of cultivation $=$ Total Fixed Cost + Total Variable Cost

\section{Depreciation on fixed capital}

The depreciation rates for different farm assets were taken as @ 10\% per annum.

\section{Net income}

Net income $=$ Total revenue - Total expenditure for one crop

\section{Results and Discussion}

The mushroom production activity is low investment indoor activity. Cultivation technology of oyster mushroom is very simple which does not require costly infrastructure facilities. Theoretically each crop takes 45- 55 days and under controlled conditions and hence there can be 8 crops per year. The mushroom from each bag was harvested and weighed periodically.

In this experiment first seeding was done in the month of January and the subsequent bags in the succeeding month.

The crop of oyster mushroom was harvested in four flushes (Table 1). 
Fig.1 Yield and economic analysis of oyster mushroom

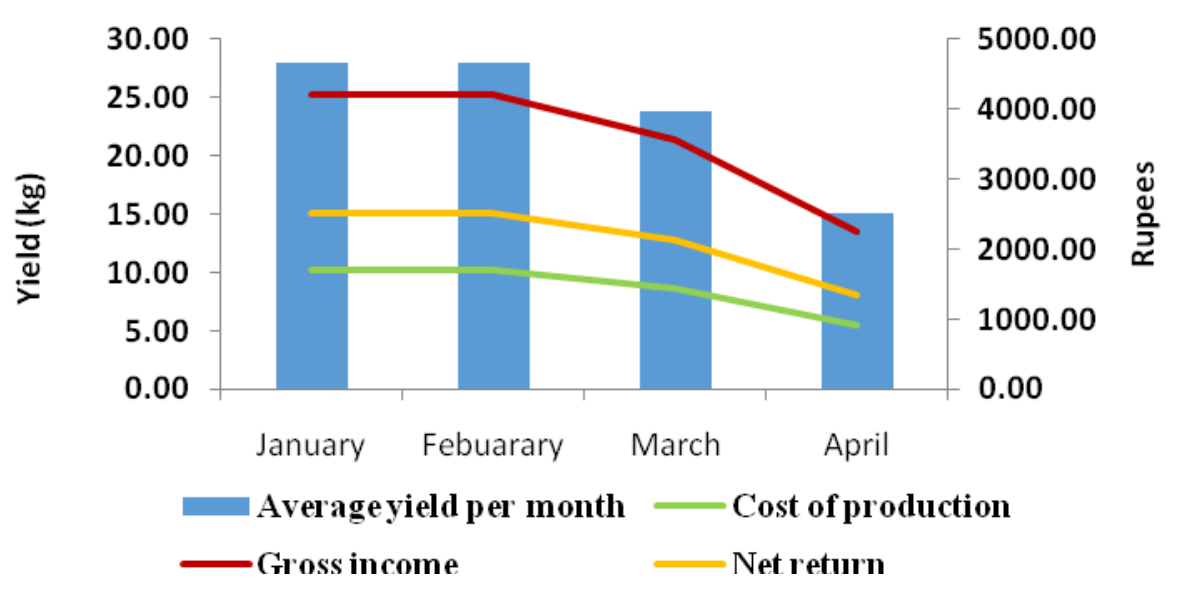

Table.1 Yield of oyster mushroom in consecutive months

\begin{tabular}{|l|c|c|c|c|}
\hline \multicolumn{1}{|c|}{ Parameters } & \multicolumn{4}{|c|}{ Mushroom yield (kg) } \\
\cline { 2 - 5 } & January & February & March & April \\
\hline $\mathbf{1}^{\text {st }}$ Harvest & 7.83 & 7.72 & 6.85 & 6.82 \\
\hline $\mathbf{2}^{\text {nd }}$ Harvest & 11.28 & 11.03 & 10.51 & 5.59 \\
\hline $\mathbf{3}^{\text {rd }}$ Harvest & 5.82 & 6.96 & 5.99 & 2.54 \\
\hline $\mathbf{4}^{\text {th }}$ Harvest & 3.14 & 2.31 & 0.5 & 0.15 \\
\hline Total & 28.059 & 28.007 & 23.839 & 15.095 \\
\hline
\end{tabular}

Table.2 Economic analysis of mushroom production

\begin{tabular}{|l|c|c|c|c|}
\hline \multicolumn{1}{|c|}{ Parameters } & January & February & March & April \\
\hline $\begin{array}{l}\text { Average yield per month } \\
\text { (kg) }\end{array}$ & 28.06 & 28.01 & 23.84 & 15.10 \\
\hline Cost of production (Rs) & 1701.22 & 1698.06 & 1445.36 & 915.210 \\
\hline Gross income (Rs) & 4205.76 & 4197.97 & 3573.23 & 2262.59 \\
\hline Net return (Rs) & 2504.55 & 2499.90 & 2127.87 & 1347.38 \\
\hline
\end{tabular}


Table.3 Cost of production of oyster mushroom

\begin{tabular}{|c|c|c|}
\hline & Particulars & Price (Rs.) \\
\hline \multirow[t]{6}{*}{ a } & \multicolumn{2}{|l|}{ Non-Recurring Expenditure } \\
\hline & Building cost & 20000 \\
\hline & Sprayer pump (1 no.) & 1500 \\
\hline & Galvanized tubs (2 no.) & 600 \\
\hline & Jute Bags 25no’s @ Rs.10 per bag + Nylon ropes & 500 \\
\hline & Total & 22600 \\
\hline \multirow[t]{10}{*}{ b } & \multicolumn{2}{|l|}{ Recurring Expenditure } \\
\hline & Paddy straw 5 bales @ Rs. 300.00 & 1500 \\
\hline & Polythene bags 150 gauge thick of $60 * 45 \mathrm{~cm} @$ Rs.100/kg $(2 \mathrm{~kg})$ & 200 \\
\hline & Cost of spawn Rs.30/packet (20 no's) & 600 \\
\hline & Formaldehyde 5 litre (commercial grade) @ Rs. 40.00 per litre & 200 \\
\hline & Miscellaneous & 1000 \\
\hline & Total & 3500 \\
\hline & Depreciation (Non Recurring Expenditure) @ 10\% & 2260 \\
\hline & Total for one year & 2260 \\
\hline & Total expenditure & 5760 \\
\hline \multirow[t]{5}{*}{ c } & Revenue & \\
\hline & From mushroom 95 kg @ Rs. 200 per kilogram & 19000 \\
\hline & By-Product & 1000 \\
\hline & Total Revenue & 20000 \\
\hline & Net Profit & 14240 \\
\hline
\end{tabular}

The maximum yield was recorded in the month of January of about $28.06 \mathrm{~kg}$. The month April had showed reduced yield of about $15.10 \mathrm{~kg}$. This reduced yield might be due to the month April showed high temperature $\left(37^{\circ} \mathrm{C}\right.$ to $\left.40^{\circ} \mathrm{C}\right)$ and low relative humidity resulted in low yield. This showed that the yield of mushroom was significantly influenced by temperature and relative humidity. Malformed mushrooms due to high temperature and low relative humidity.

The overall yield improvement in first and second seeding in the month of January and February as explained due to optimum temperature and relative humidity for the development of mycelium, which helped in improving the yield of mushroom.

In order to determine whether the businesses peoples producing mushroom were profitable or not, cost analysis of mushroom production was carried out in cost benefit analysis, it is important to examine the initiatives undertaken by the producer. The main inputs required for oyster mushroom cultivation are substrate and spawn. 
The total expenditure was about Rs.5760. Spawn is the main input of mushroom production. The average cost of spawn per bags was about Rs.30. The economic analysis further revealed that the cost of production per kilogram of mushroom was Rs. 60.63. Gross return was Rs. 20000/-. The net return was about Rs.14240. The returns per kilogram came about Rs. 149.89 (Fig. 1; Table 2 and 3).

The spent mushroom substrate converted into organic compost and sold to farmers was about Rs.1000. The farmers can further reduce the cost of mushroom production by producing spawn for their own requirement. A low cost spawn laboratory using small autoclave, inoculation chamber or laminar flow will be appropriate as the mycelium of oyster mushroom is very fast growing and in 10-12 days spawn can be prepared with little practice. This can be recommended that mushroom growing is a profitable enterprise in Tiruchirappalli.

India produces about 600 million tonnes of agricultural waste per annum and a major part of it is left out to decompose naturally or burnt in situ. This can effectively be utilized to produce highly nutritive food such as mushrooms and spent mushroom substrate can be converted into organic manure/vermicompost. By just diverting $1 \%$ of agro-wastes towards mushroom production, India can produce 3 million tonnes of mushroom and about 15 million tonnes of compost. To conclude that this small initiative by the student generation will serve as a role-model for others and create awareness among fellow student community.

\section{References}

Bano, Z., Rajarathnam, S., and Nagaraja, N. (1987). Some important studies on Pleurotus mushroom technology. In International conference on science and cultivation technology of edible fungi. Jammu Tawi, India (pp. 53-64).

Çağlarırmak, N. (2007). The nutrients of exotic mushrooms (Lentinula edodes and Pleurotus species) and an estimated approach to the volatile compounds. Food chemistry, 105(3), 1188-1194.

Das, N., and Mukherjee, M. (2007). Indoor Cultivation of $P$. ostreatus. Philo Agric, 61, 253-262.

Dundar, A., Acay, H., and Yildiz, A. (2008). Yield performances and nutritional contents of three oyster mushroom species cultivated on wheat stalk. African Journal of Biotechnology, 7(19).

Eswaran, A., and Ramabadran, R. (2000). Studies on some physiological, cultural and postharvest aspects of oyster mushroom, Pleurotus eous (Berk.) sacc.

Kalač, P. (2009). Chemical composition and nutritional value of European species of wild growing mushrooms: A review. Food chemistry, 113(1), 9-16.

Khan, A. M., Khan, S. M., and Khan, S. M. (2001). Studies on the cultivation of Oyster mushroom Pleurotus ostreatus on different substrates. Pakistan J. Phytopath, 13(2), 140-143.

Pathmashini, L., Arulnandhy, V., and Wijeratnam, R. S. (2009). Cultivation of oyster mushroom (Pleurotus ostreatus) on sawdust. Ceylon Journal of Science (Biological Sciences), 37(2).

Srivastava, H. C., and Bano, J. (2010). Studies on the cultivation of Pleurotus species on paddy straw. Food Sci, 11, 36-38.

\section{How to cite this article:}

Chitra, K., R. Venkatesh, K. Dhanalakshmi, P.T. Sharavanan, C. BaliSasikumar and Karthikeyani Vijayakumari, K. 2018. Production and Economic Analysis of Oyster Mushroom (Pleurotus florida). Int.J.Curr.Microbiol.App.Sci. 7(09): 379-383. doi: https://doi.org/10.20546/ijcmas.2018.709.046 